legs. They worked out, from the amount of fuel that they had and according to the forecast temperatures, how fast they could fly at various heights. They then added to that what the winds were at various heights, which obviously gave them the height at which they could fly fastest. The R.A.A.F. planning was rather less flexible than that of the R.A.F.; on the other hand, it was extremely tight and keen.

Flight Lieutenant Burton: There is one point which has not been brought out and which we should not let pass. The actual in-flight times of all five Canberras were very similar-they were in fact all within a bracket of nine minutes. The fastest aircraft took 22 hours 22 minutes and the slowest 22 hours $3 \mathrm{r}$ minutes. This seems quite remarkable on a flight of over 10,000 miles.

The Chairman: I am sure you would wish me to congratulate Wing Commander Hodges and his team on their success and also to congratulate them on the able way in which they have set out the details of their very arduous training and the many interesting aspects of the flight itself.

I was particularly impressed by Flight Lieutenant Burton's description of the pre-flight training. I do not know whether you were aware of what was going on before this race; I certainly was not. Trips round the United Kingdom, to Malta, Shaibah and then down to Negombo and the Cocos Islands and back all formed an essential part of the training. Some may think that that must have used up a lot of fuel, but I whole-heartedly support what the team said, in summing-up, as to the value of the air race. I am sure we cannot overestimate the amount which has been learnt, and can only be learnt, by this sort of approach. It is therein that the value of such races lies. Having listened to this account I feel certain that every penny spent on the race and on the preparation for it brought an exceedingly valuable return.

You will have noticed that it is still the little things which make or mar these endeavours. Nothing was wrong with the airframe or the engines; any difficulties were caused by filler caps, generators and so on. It is extraordinary how these small mishaps dog all who go in for racing. Finally it is interesting to see how temperature is coming more and more into aviation: temperature seems now to point the height at which to fly and to limit the speed. And as we fly faster and faster temperature becomes probably the biggest problem of all.

I will now ask you to show your appreciation of their work and of the manner in which they have presented this account.

\title{
VICE-ADMIRAL DE AQUINO
}

The Institute has received notice of the death, on 8 October 1953, of ViceAdmiral Francisco Radler de Aquino, Brazilian Navy. Admiral de Aquino was elected an Honorary Member of the Institute in 1949. It is hoped to publish an appreciation of his work in a future number of the Journal. 